\title{
The Discussion on Input - Output Framework Extended for Analyzing on Relationship between Demographic and Economic
}

\author{
Nguyen Quang Thai ${ }^{1}$, Bui Trinh ${ }^{1}$, Nguyen Hong Nhung ${ }^{2}$ \\ ${ }^{1} \mathrm{PhD}$, Vietnam Development Research Institute, Vietnam \\ ${ }^{2}$ Vietnam Development Research Institute, Vietnam \\ Correspondence: Bui Trinh, PhD, Vietnam Development Research Institute, Vietnam.
}

Received: April 23, 2019

doi:10.5539/ibr.v12n6p52

\begin{abstract}
So far, many studies on economic structure have been proposed, Studies on the relationship between demographics and communication economics basically consider changes in age structure, leading to changes in saving and investment capacity. In Miyazawa's demographic-economic model, the focus has been on quantifying the relationship of final consumer groups and corresponding income groups. This study tries to establish the relationship between age and output and income. This study tries an attempt to extended Miyazawa's model which gross capital formation at columns and operating surplus at rows. That means the input - output system was not only extended aging group at consumption of employees at rows and final household consumption at columns, but alsoadd to gross capital formation at columns and total income of producers (operating surplus and exogenous income) at rows. In this system, it is allowed to consider changing population structure which not only affects economy through saving or investment but also the structure of final consumption by age also spreads to output and income. So, in this research is not only this related inter-sartorial at first-time distribution for considering but also the impact of demographic to economic activities and re-distribution income follow by type of aging group.
\end{abstract}

Keywords: consumption, demographic, economic, gross capital formation, input, output, value added

\section{Introduction}

The attempt to find an interaction between population and economy seems to be the goal of economic researchers; typical classical economists interested in the demographic-economic relationship are TR Malthus (1766 -1834) $)^{1}$, Adam Smith (1723 - 1790) and David Ricardo (1772 - 1823). However, their theory is rarely expressed in the form of mathematical expressions.

Coale\& Edgar M. Hoover (1958) argued that structural change of the number leads to changes in the structure of the economy through savings and investment, from changes in population structure can leading to economic growth and it is considered a demographic gift. David Bloom and Jeffrey Williamson (1997), Ahlburg, Dennis A (1987) and Barro, Robert J. (1997)found the impact between economic growth and Population Growth in development countries.

Since, Leontief's Input-Output System (IOS) came out into $(1936,1941)$, it has been further developed and expanded in many ways by various researchers. Moreover, including originally inter-regional input-output table by Isard (1951), multi-regional input-output model (MRIO) by Chenery (1954) and Moses (1955) and Miller, Blair (1985); Social accounting system by Stone (1961) Pyatt and Rose (1977). Demographic - economic model was parallel developed with social accounting matrix by Miyazawa (1976) and Madden and Batey (1983), Demographic - economic model has been developed by Miyazawa for analyzing the structure of income distribution by endogenous consumption expenditures in the standard of Leontief system. It means the Leontief

\footnotetext{
${ }^{1}$ Malthus was an English reverend (1766-1843), who in his book "An Essay on the Principles of Population" wrote an argument against his contemporary Mr. Godwin, who believed in unlimited population growth. Malthusian population theory warned of the possibility, that while the population grew geometrically, food resources grew only in arithmetical proportion, thus creating the conditions for a shortage in the long term that would require an adjustment in the birth rate.
} 
system was extended by a group of consumption expenditures in column and corresponding group of row income. In 2019, Nhung N.H, Thai N.Q, Trinh. B, Phong N.V (2019) applied this model for analyzing on rural and urban in Vietnam economic structure.

There are some research on economic structure based on input - output analysis such as Hussain AliBekhet (2009) also used input - output approach in order to decompose of Malaysian production structure and calculating output, income, employment multipliers in Malaysian Economy, this author also used input - output system for ranking Sectors Changes of the Malaysian economy (2010), B.Trinh, B.Quoc (2017) applied input output system in order to research on industrial Structure, GDP Growth and sustainability of Vietnam, Bui Trinh, Kiyoshi Kobayashi, T. D. Vu, P. L.Hoa \& Nguyen Viet Phong (2012) also used input - output model for forecasting Economic Structure for Vietnam Toward Sustainable Economic Growth in 2020

This study tries an attempt to extended Miyazawa's model which investment at columns and operating surplus at rows. That means the input - output system was not only extended by type of aging groups at consumption of employees at rows and final household consumption at columns, but also gross capital formation at columns and total income of producers (operating surplus and exogenous income) at rows. In this system, it is allowed to consider changing population structure which not only affects economy through saving or investment but also the structure of final consumption by age also spreads to output and income. So, in this research is not only this related inter-sartorial at first-time distribution for considering but also the impact of demographic to economic activities and re-distribution income follow by type of age group.

Study was using input - output tables in 2012, 2016 and merging the data sources of input-output system, population census and household expenditure surveys for finding the change on impact of demographic to economy

\section{Methodology}

This research uses type I and type II of Leontief system.

Type I of input-output analysis is based on standard equation of Leontief system:

$$
\mathrm{X}=\left(\mathrm{I}-\mathrm{A}^{\mathrm{d}}\right)^{-1} \cdot \mathrm{Y}^{\mathrm{d}}
$$

In this type, We get power of dispersion and sensitivity of dispersion for output and income matrix that is included impacts by factors of final demand. In this case, $\mathrm{X}$ is matrix of output that induced by factors of final demand, $\mathrm{I}$ is unit matrix, $\mathrm{A}^{\mathrm{d}}$ is domestic direct input coefficient, $\mathrm{Y}^{\mathrm{d}}$ is matrix of domestic final demand that defined as:

$$
\mathrm{Y}^{\mathrm{d}}=\mathrm{Y}^{\mathrm{d}}\left(\mathrm{C}_{1}, \mathrm{C}_{2}, \mathrm{C}_{3}, \mathrm{I}, \mathrm{G}, \mathrm{E}\right)
$$

$\mathrm{C}_{1}, \mathrm{C}_{2}, \mathrm{C}_{3}$ are final consumption present before working ages, in the working ages, past the working ages corresponding, $\mathrm{I}$ is vector of gross capital formation, $\mathrm{G}$ is vector of Government consumption expenditure, $\mathrm{E}$ is vector of export. In order to estimate value added induced by a unit of final demand the equation (1) can rewritten as below:

In order to estimate value added induced by a unit of final demand the equation (1) can rewritten as below:

$$
\mathrm{V}=\mathrm{v} \cdot \mathrm{X}=\mathrm{v} \cdot\left(\mathrm{I}-\mathrm{A}^{\mathrm{d}}\right)^{-1} \cdot \mathrm{Y}^{\mathrm{d}}
$$

Where: $\mathrm{V}$ is matrix of value added with rows presents type of income and columns are sectors; $\mathrm{v}$ is matrix value added coefficient, with: $\mathrm{v}_{\mathrm{ij}}=\mathrm{V}_{\mathrm{ij}} / \mathrm{X}_{\mathrm{j}}$

And:

$$
\begin{gathered}
\mathrm{X} \div \mathrm{Y}^{\mathrm{d}} \text { present impacts of factors of final demand to output } \\
\mathrm{V} \div \mathrm{Y}^{\mathrm{d}} \text { presents impacts of factors of final demand to value added }
\end{gathered}
$$

Here: $\div$ shows scalar division

The equation (2) shows induced impacts of each factor of final demand to components of value added, for example, it can measure how much final consumption of type of ages induce to components of value added. This shows that the structure of age does not only affect the economy from changes in savings / investment but also depends on the final consumption factor of each type of age spreading to the production and income.

Type II is an expansion Leontief system and Miyazawa model. The study considers the following systems:

$$
\begin{aligned}
& \text { A.X }+\mathrm{c}_{1} \cdot \mathrm{T}_{1}+\mathrm{c}_{\mathrm{i}} \cdot \mathrm{T}_{\mathrm{i}}+\ldots+\mathrm{c}_{\mathrm{n}} \cdot \mathrm{C}_{\mathrm{n}}+\mathrm{k} \cdot \mathrm{Tc}+\mathrm{E}=\mathrm{X} \\
& \mathrm{v}_{\mathrm{i}} \cdot \mathrm{X}+\mathrm{V}_{\mathrm{i}}{ }_{\mathrm{i}}+\mathrm{V}{ }_{\mathrm{i}}+\mathrm{V}{ }{ }_{\mathrm{I}}+\mathrm{V},{ }{ }_{\mathrm{i}} \quad=\mathrm{T}_{\mathrm{i}}
\end{aligned}
$$




$$
\mathrm{v}_{\mathrm{c}} \cdot \mathrm{X}+\mathrm{V} \text { 'c } \quad=\mathrm{Tc}
$$

Where: $\mathrm{V}_{\mathrm{i}} \cdot \mathrm{X}=\mathrm{V}_{\mathrm{i}} ; \mathrm{v}_{\mathrm{c}} \cdot \mathrm{X}=\mathrm{V}_{\mathrm{c}} ; \mathrm{i}=(1, \mathrm{n})$ is number of type aging groups

$\mathrm{V}_{\mathrm{i}}$ and $\mathrm{V}_{\mathrm{c}}$ are production income of labor and capital corresponding, $\mathrm{X}$ is an vector of output;

And:

A is matrix of direct input coefficients;

$\mathrm{V}^{\prime}{ }_{\mathrm{i}}(\mathrm{i}=1, \mathrm{n})$ is exogenous income of aging group $\mathrm{i}$ that receipted by other aging groups

$\mathrm{V}{ }^{\prime}{ }_{\mathrm{i}}(\mathrm{i}=1, \mathrm{n})$ is exogenous income of aging group $\mathrm{i}$ that receipted by transferring of Government institutional

$\mathrm{V}$ "' $\mathrm{i}(\mathrm{i}=1, \mathrm{n})$ is exogenous income of aging group $\mathrm{i}$ that receipted by production sector

$\mathrm{V}$ "', $\mathrm{i}(\mathrm{i}=1, \mathrm{n})$ is exogenous income of aging group $\mathrm{i}$ that receipted by transferring from abroad.

$\mathrm{T}_{\mathrm{i}}$ is total income of aging group $\mathrm{i}$, Tc is total income on capital, it includes share of capital $\left(\mathrm{v}_{\mathrm{c}} \cdot \mathrm{X}\right)$ and capital transfer (V'c),

$\mathrm{c}_{1}, \mathrm{c}_{\mathrm{n}}$ are coefficients vectors of final household consumption of household by aging group $\mathrm{i}^{\text {th }}$, household consumption of product $\mathrm{i}\left(\mathrm{C}_{\mathrm{i}}(\mathrm{i})\right)$ defined as below:

$$
\mathrm{c}_{\mathrm{i}}(\mathrm{i})=\mathrm{C}_{\mathrm{i}}(\mathrm{i}) / \mathrm{T}_{\mathrm{i}}(\mathrm{i})
$$

$\mathrm{k}$ is a vector coefficient of gross capital formation $(\mathrm{K})$, that element $\mathrm{k}_{\mathrm{i}}$ was defined:

$$
\mathrm{k}_{\mathrm{i}}(\mathrm{i})=\mathrm{K}_{\mathrm{i}} / \mathrm{Tc}(\mathrm{i})
$$

Tc is total income on capital (including operating surplus and capital transfer income),

Put:

$$
\mathrm{B}=\left(\begin{array}{lll}
A & c_{i} & k \\
v_{i} & \\
v_{c} &
\end{array}\right)
$$

The equation system (1), (2), (3),(4),(5) and (6) can be rewritten in a matrix form like standard Leontief equation with endogenous and exogenous variables of incomes and expenditures and we have:

$$
\left(\begin{array}{c}
X \\
T_{i} \\
T_{C}
\end{array}\right)=(\mathrm{I}-\mathrm{B})^{-1} \cdot\left(\begin{array}{c}
E \\
\theta \\
V_{C}^{\prime}
\end{array}\right)
$$

Where $\mathrm{I}$ is an unit matrix, $\theta=\mathrm{V}{ }_{\mathrm{i}}+\mathrm{V},{ }_{\mathrm{i}}+\mathrm{V},{ }_{\mathrm{I}}+\mathrm{V},{ }^{\prime \prime}{ }_{\mathrm{i}}$

And Put: $\mathrm{L}=(\mathrm{I}-\mathrm{B})^{-1}$

$$
\mathrm{L}=(\mathrm{I}-\mathrm{B})^{-1}=\left(\begin{array}{lll}
L^{A} & L^{C i} & L^{k} \\
L^{V_{i}} & H \\
L^{V c} &
\end{array}\right)
$$

$\mathrm{L}$ is computed based on Sonis and Hewings work (1993) where: 
$L^{A}$ is called enlarged Leontief inverse matrix. It includes multiplier effects $(I-A)^{-1}$ and induced feedback effects by $\mathrm{L}^{\mathrm{Ci}}$, and $\mathrm{L}^{\mathrm{k}}$. To be explicit, we have:

$$
\mathrm{L}^{\mathrm{A}}=\left(\mathrm{I}-\mathrm{A}-\mathrm{c}_{\mathrm{i}} \cdot \mathrm{T}_{\mathrm{i}}-\mathrm{k} \cdot \mathrm{T}_{\mathrm{c}}\right)
$$

$\mathrm{L}^{\mathrm{Vi}}$, and $\mathrm{L}^{\mathrm{k}}$ are income multipliers that spillover effects caused by final consumption and gross capital formation, we have:

$$
\mathrm{M}\left(\mathrm{L}^{\mathrm{Vi}}, \mathrm{L}^{\mathrm{k}}\right)=\mathrm{M}\left(\mathrm{V}_{\mathrm{i}}, \mathrm{V}_{\mathrm{c}}\right) \mathrm{L}^{\mathrm{A}}
$$

Applying Miyazawa explained matrix, we have:

$$
M\left(L^{c i}, L^{k}\right)=(I-A)^{-1} \cdot M\left(c_{i}, k\right) \cdot H=L^{A} \cdot M\left(c_{i}, k\right)
$$

With: $M\left(c_{i}, k\right)$ is sub-matrix of extended matrix $B$ and $M\left(L^{c 1}, L^{c 2}, L^{c 3}, L^{k}\right)$ is sub- matrix of matrix $L$. The number of row of this matrix is equal to the number of sectoral of the input-output table, and its number of column is the additional numbers of row as of Leontief extended matrix.

$\mathrm{H}$ is an enlarged matrix of Miyazawa interrelation income multipliers. This means exogenous income induced impact on redistribution of income. It causes spillover effects to production through household consumption by age, since we have:

$$
\mathrm{H}=\mathrm{I}+\mathrm{M}\left(\mathrm{V}_{1 \mathrm{i}}, \mathrm{V}_{\mathrm{C}}\right) \cdot \mathrm{L}^{\mathrm{A}} \cdot \mathrm{M}\left(\mathrm{c}_{\mathrm{i}}, \mathrm{k}\right) .
$$

It implies that final expenditure stimulates income outside of production

So, Formula (10) can be rewritten:

$$
\mathrm{L}=\left[\begin{array}{cc}
L^{A} & L^{A} \cdot M\left(c_{i}, k\right) \\
M\left(V_{i}, V c\right) \cdot L^{A} & I+M\left(V_{i}, V c\right) \cdot L^{A} \cdot M\left(c_{i}, k\right)
\end{array}\right]
$$

\section{Conclusion}

With the above arguments, it is hoped to find new conclusions: With the same input conditions, it is hoped that the output of this extension model can obtain "non-linear" results, depending on belonging to "integrated"relations. This research question is being applied to Vietnam's economy data and new search results will be presented in a subsequent article.

We hope that in the future, it will present some findings based on the proposed model with data based on the use of input tables - outputs for 2012, 2016 and consolidation of system data sources. input, census and household expenditure survey in Vietnam. Hopefully there will be "non-linear" results, which are not linear and relations have been "integrated".

\section{References}

Ahlburg, D. A. (1987a). "The Impact of Population Growth on Economic Growth in Developing Nations: The Evidence from Macroeconomic-Demographic Models." In Population Growth and Economic Development: Issues and Evidence, ed. D. Gale Johnson and Ronald D. Lee. Madison: University of Wisconsin Press.

Barro, R. J. (1997). "Determinants of Economic Growth”. Cambridge, MA: MIT Press.

Batey, P. W. J., \& Madden, M. (1983). "The modeling of demographic-economic change within the context of regional decline: analytical procedures and empirical results". Socio-Economic Planning Sciences, 17(5-6), 315-328.

Bloom, D., \& Jeffrey, G. W. (1998). "Demographic Transitions and Economic Miracles in Emerging Asia." World Bank Economic Review, 12, 419-455.

Bui, T., \& Bui, Q. (2017). "Some Problems on the Sectoral Structure, GDP Growth and Sustainability of Vietnam". Journal of Reviews on Global Economics, pp. 143 - 153.

Bui, T., Kiyoshi, K., Trung-Dien, V., Pham, L. H., \& Nguyen, V. P. (2012). "New Economic Structure for Vietnam Toward Sustainable Economic Growth in 2020". Global Journal of HUMAN SOCIAL SCIENCE Sociology Economics \& Political Science, 12(10).

Chenery H. B. (1954). "Interregional and international input output analysis, the structure interdependence of economy", in T. Barna (ed), proceeding of an international on input output analysis conference, New York, Milano, Gruffer. 
Coale, E. J., \& Edgar, M. H. (1958). Population Growth and Economic Development in Low-Income Countries. Princeton, NJ: Princeton University Press.

David, E. B., \& Jeffrey, G. W. (1997) Demographic Transitions and Economic Miracles in Emerging Asia, NBER Working Paper No. 6268.

Hussain, A. B. (2009) Decomposition of Malaysian Production Structure Input-Output Approach. International Business Research, 2(4).

Kelley, A. C., \& Robert, M. S. (2001). "Economic and Demographic Change: A Synthesis of Models, Findings, and Perspectives." In Population Matters: Demographic Change, Economic Growth, and Poverty in the Developing World, ed. Nancy Birdsall, Allen C. Kelley, and Steven W. Sinding. Oxford: Oxford University Press.

Lee, R. D., Andrew, M., \& Tim, M. (2001). "Saving, Wealth and Population." In Population Matters: Demographic Change, Economic Growth, and Poverty in the Developing World, ed. Nancy Birdsall, Allen C. Kelley, and Steven W. Sinding. Oxford: Oxford University Press.

Leontief, W. W. (1936). "Quantitative Input and Output Relations in the Economic Systems of the United States". The Review of Economics and Statistics, 18, 105-125.

Lutz, W. ed. (1994). Population-Development-Environment: Understanding Their Interactions in Mauritius. Berlin: Springer-Verlag.

Lutz, W., Alexia, P., \& Warren, C. S. eds. (2002). Population and Environment: Methods of Analysis. Supplement to Population and Development Review, 28.

Malthus, T. R. (1798). An Essay on the Principle of Population. J. Johnson, in St. Paulís Church-Yard, London, UK.

Miller, R., \& P. Blair. (1985). Input-Output Analysis: Foundations and Extensions, Chapter 7 (pp. 236-260), Environmental Input-Output Analysis, Prentice-Hall.

Miyazawa, K. (1976). Input-Output Analysis and the Structure of Income Distribution. Lecture Notes in Economics and Mathematical Systems, Berlin: Spinger-Verlag.

Moses, L. M. (1955). The stability of interregional trading patterns and input-output analysis. American Economic Review, 45(5), 803-832.

Nguyen, H. N., Nguyen, Q. T., Bui, T., \& Nguyen, V. P. (2019) "Rural and Urban in Vietnam Economic Structure". International Business Research; 12(3), 31-39.

Pyatt, G., \& Roe, A. N. (1977). Social Accounting for Development Planning with Special Reference to Sri-Lanka, Cambridge: Cambridge University Press.

Ricardo, D. (1919). Principles of Political Economy and Taxation. G. Bell, p. lix: "by reason of a religious difference with his father, to adopt a position of independence at a time when he should have

San Diego Association of Governments. (1993). DEFM Forecast 1993 to 2015. Volume 1: Model Overview. San Diego, CA: San Diego Association of Governments.

Sanderson, W. C. (1980). Economic-Demographic Simulation Models: A Review of the Usefulness for Policy Analysis. Ladenburg, Austria: International Institute for Applied Systems Analysis.

Simon, J. L. (1977). The Economics of Population Growth. Princeton, NJ: Princeton University Press.

Smith, A. (1776). An Inquiry into the Nature and Causes of the Wealth of Nations. 1 (1 ed.). London: W. Strahan. Retrieved 7 December 2012., volume 2.

Sonis, M. G., \& Hewings, J. D. (1993). Hierarchies of regional sub-structure and their multipliers within input output systems: Miyazawa revisited Hitotsubashi. Journal of Economics, 34, 33-44.

Stone, R. (1961). Social accounts at the regional level: a survey. In Regional Economic Planning, Techniques of Analysis (W, Isard and J. H. Cumberland, eds), pp. 263-296. Paris: O.E.E.C.

Trinh, B., \& Phong, N. V. (2013). "A Short Note on RAS Method". Advances in Manage Report of ment and Applied Economics, 3(4), 133-137.

Trinh, B., Phong, N. V., \& Quoc, B. (2018). "The RAS Method with Random Fixed Points" The Asian Institute of Research. Journal of Economics and Business, 1(4), 640-646.

Walter, I. (1951). "Interregional and Regional Input-Output Analysis: A Model of a Space-Economy", 
Cambridge, the MIT Press.

Wassily, L. (1941). Structure of the American economy, 1919-1929. Harverd University Press: Cambridge Mass.

Werner, Z. H. (1959). “An Application of Area Input - Output Analysis”. Regional Science, 5(1), 79-92

\section{Copyrights}

Copyright for this article is retained by the author(s), with first publication rights granted to the journal.

This is an open-access article distributed under the terms and conditions of the Creative Commons Attribution license (http://creativecommons.org/licenses/by/4.0/). 